\title{
Chapter 10 \\ Phylogeography and the Role \\ of Hybridization in Speciation
}

\author{
Leo Joseph
}

\begin{abstract}
Human beings have a strong, innate desire to classify and name things. We like things to be clear-cut. The way we approach classification of birds is as good an example as any of this. So it always comes as something of a surprise to non-ornithologists to learn that how we classify birds at the level of the species around us is still subject of so much at times fiery debate. Various chapters in this book approach this from different perspectives. In this chapter, the focus is on reminding us that evolution is an ongoing, dynamic process and that appreciating this evolution can help us make sense of why it is sometimes so complicated to pin names on birds and indeed many other organisms. This will take us into a few particular aspects of bird evolution. One will be the process of hybridization between populations that may or may not be of the same species or between species that may or may not be each other's closest relatives. Another will concern the study of genetic diversity that exists within a species. In particular, we will examine what we have learned from the way that that diversity has come to be apportioned and distributed across the geographical range and landscapes inhabited by a species. These two areas have opened windows into the dynamics of evolution that give us new understanding of bird species. Genetic boundaries between species and subspecies are frequently very "leaky." Only certain parts of the genome, the entire complement of genetic material in a species, may be contributing to the differences that we can see between bird species. If the chapter can convey to the reader that we must learn to think of birds as continually evolving evolutionary lineages, then it will have had some success.
\end{abstract}

Keywords Birds $\cdot$ Speciation $\cdot$ Hybrid zones $\cdot$ Phylogeography $\cdot$ Genomics

\footnotetext{
L. Joseph $(\bowtie)$

Australian National Wildlife Collection, National Research Collections Australia, CSIRO,

Canberra, ACT, Australia

e-mail: Leo.Joseph@csiro.au

(C) The Author(s) 2018

D. T. Tietze (ed.), Bird Species, Fascinating Life Sciences,

https://doi.org/10.1007/978-3-319-91689-7_10
} 


\subsection{Introduction}

Phylogeography, hybridization, and speciation are inextricably intertwined. To help explain this and to chart a course for this chapter, some definitions and discussion are needed at the outset.

Phylogeography was originally conceived as a bridge between population genetics and systematics formed by analyses of mitochondrial DNA (mtDNA) (Avise et al. 1987). Its goals have always been to describe patterns of genetic diversity within a species across its geographical distribution and to understand the processes driving those patterns. Its molecular scope grew to include multilocus data, a term that in practice describes inclusion of up to 30 single regions of the nuclear genome. Currently, the tools of genomics enable genetic diversity to be studied across the entire genome, often including thousands of single sites that vary within and between species-single nucleotide polymorphisms or SNPs. Phylogeographic data are usually characterized by extensive sampling of individuals across the range of a species. This contrasts with the smaller number of individuals and higher number of loci that can suffice when estimating phylogenetic relationships among species and higher taxa (Nei and Roychoudhury 1974). Phylogeography and phylogeny are increasingly less discrete in scope (Smith et al. 2014a) but are reasonably seen as different parts of a continuum (Edwards et al. 2016).

Phylogeographic data enable tests of biogeographic hypotheses, description of the evolution of reproductive isolation, inference of processes underlying the origin, distribution and maintenance of biodiversity, and inferences about temporal changes in a population's physical and biotic environments (Beheregaray 2008). Revisions of species boundaries and taxonomic changes are prompted by phylogeographic data (especially when integrated with other data sets). Examples in birds abound [e.g., from Australia (Dolman and Joseph 2015, 2016; McLean et al. 2017a, b); from Eurasia (Olsson et al. 2013); from the Americas (Cadena and Cuervo 2010; Harvey and Brumfield 2015; Oswald et al. 2016); from Africa (Bowie et al. 2009; Voelker et al. 2013)]. Often, phylogeographic studies reveal much previously unknown (cryptic) but strongly geographically structured genetic diversity within a species. When researchers understandably try to understand the drivers of that diversity (Smith et al. 2014b; Harvey et al. 2017), one often has a sense of unfinished taxonomic business. Alternatively, cryptic population structure revealed by phylogeography can open very different, non-taxonomic windows of research into how natural selection has operated at the molecular level (Ribeiro et al. 2011; Pavlova et al. 2013). I will examine some cases in this chapter.

Hybridization has been defined many ways: reproduction between different species (Rheindt and Edwards 2011) or between genetically distinct populations producing offspring of mixed ancestry (Abbott et al. 2013), for example. In molecular terms, hybridization can be seen as an invasion of one genome by another (Mallet 2005), and genomic approaches to hybridization are now commonplace (Payseur and Rieseberg 2016). Perhaps not so often appreciated, among ornithologists at least, is that hybridization can promote rather than impede differentiation and 
speciation. Hybridization can select for reinforcement of reproductive isolation and cause hybrid speciation (Barton 2013; see Italian Sparrow Passer italiae example below). Also important is what hybridization is not. It is not something that "goes wrong" long after speciation is complete nor is it some "weakness" in how two species maintain separation or reproductive isolation (see Mallet 2005).

Genomic data in phylogeography reveal even higher frequencies of movements of genes between species than had been appreciated (Edwards et al. 2016; Mallet et al. 2016): species boundaries are far more porous than supposed (Chan and Levin 2005). Introgression, the one-way movement of genes from one population into another after hybridization, and two-way gene flow explain this. The result is known as reticulation and is a rearrangement of genetic diversity within and among species as they diverge from their common ancestor. Reticulation at different taxonomic levels will recur in this chapter.

Ornithologists have long studied hybridization and the regions where it is thought to occur-hybrid zones (Sibley 1957; Short 1969; Ford 1974). Descriptions of species hybridizing are common in the literature. Books and review papers have been written about it in birds (Grant and Grant 1992; McCarthy 2006).

Speciation is the study of how two or more species evolve from a common ancestor. In birds, it too has been the subject of books (Price 2008; Newton 2004) and reviews (Friesen 2015 for marine birds; Toews et al. 2016a). Reproductive isolation between two populations is perhaps the most unequivocal criterion by which researchers will accept that two species are involved. As with hybridization, we need to stress what speciation is not. It is not the same as species delimitation, but the process by which populations diverge from their common ancestor is a component of speciation that may or may not lead to its completion. Different lenses of data, say from phylogeography, plumage variation, or ecology and behavior, coupled with different ways of defining species, can mean that different workers consider speciation complete (and so worthy of species delimitation) at different stages of the process of diverging from a common ancestor. This concept has been captured well in de Queiroz's (2007) well-known figure (Fig. 10.1). The "gray zone" described by de Queiroz (2007) is very familiar to ornithologists faced with taxonomically interpreting cases where genetic distances between two populations under study and calculated from DNA sequences are between $0.5 \%$ and $2 \%$ and few phenotypic differences are discernible (see Roux et al. 2016).

How reproductive isolation evolves is a contentious and active area of study. What it offers to species delimitation in contrast to details of how it evolves likely have no simple demarcation as this book will show. Similarly, different evolutionary and environmental histories of birds within and among different regions mean that there is no single level of genetic divergence between two populations that indicates they have completed speciation. Against that, empirical and theoretical work is showing that the process of divergence from a common ancestor can reach a rapid transition to a "tipping point" resulting in reproductive isolation (Gompert et al. 2017; Nosil et al. 2017; Yamaguchi and Iwasa 2017).

Speciation research can only benefit from case-by-case phylogeographic study of how genetic diversity is geographically distributed within and among species whose 


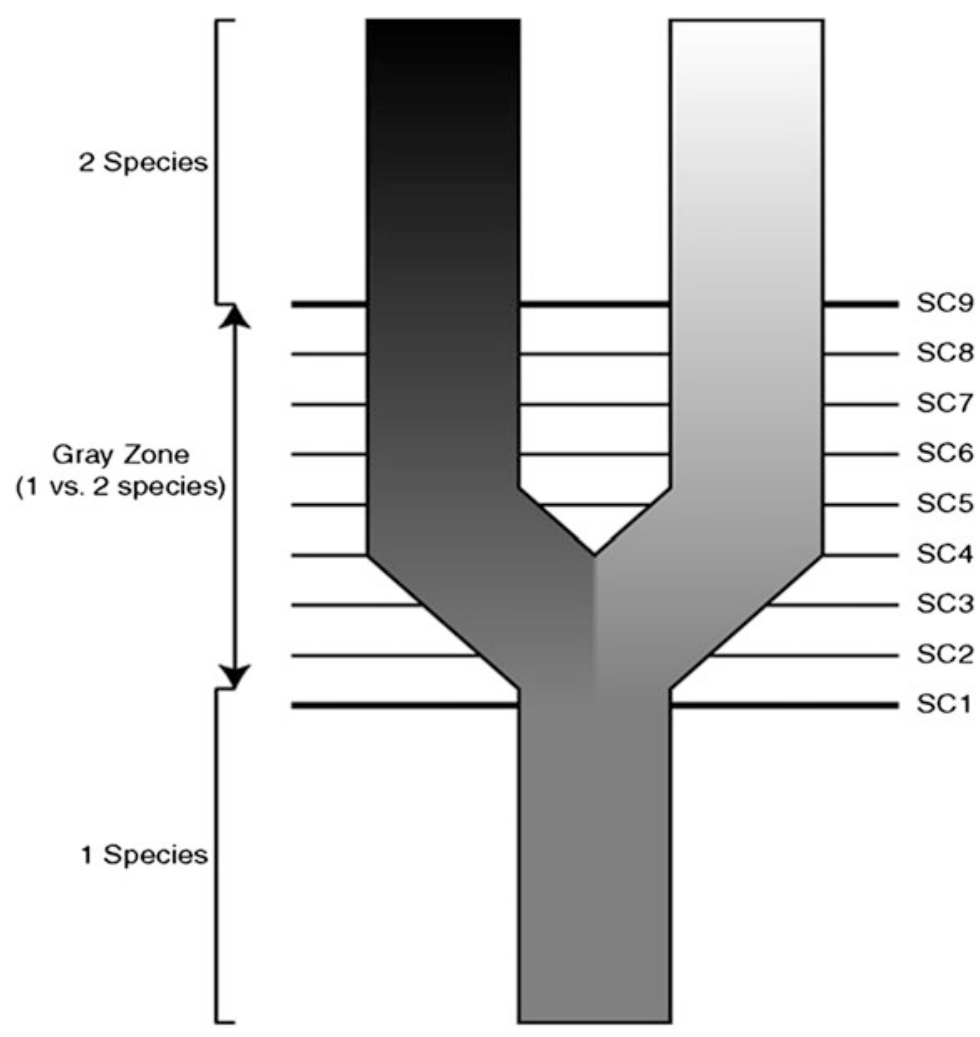

Fig. 10.1 Well-known and extraordinarily helpful figure from de Queiroz (2007) to describe how conflicts arise among different researchers when recognizing that speciation is or is not complete and when viewed through different lenses of data and species concepts (SCs)

origins we seek to understand along with consequences of hybridization (cf. Price 2008). The concepts by which we try to recognize the limits between species and so apply names to them are covered more explicitly in other chapters. One point will recur: It is often hard, if not foolhardy, to compartmentalize ongoing evolution by placing names too rigidly on many populations. Inevitably, we need to try and do so, because we need to communicate about species and their component populations, many of which are plainly and unquestioningly distinct. Yet in more and more cases to which we apply modern techniques, we learn that populations are evolutionarily more ephemeral than we perceive (Harvey et al. 2017) and nomenclature captures one phase of this change.

Tying these somewhat anticipatory threads together to form a foundation for the rest of this chapter, I note that hybridization revealed in phylogeographic studies is increasingly being stressed as a process that simply will occur almost inevitably during speciation. Gene flow happens during divergence (Smadja and Butlin 2011). Divergence and speciation in birds are not instantaneous events but can happen more easily and quickly than often thought (Mallet 2008; see Friis et al. 2016 for juncos). 
The footprint of that gene flow is detectable by analytical methods now in use, but opinions differ about its effect on and potential role in the process of speciation (Butlin and Ritchie 2013). Barton (2013), for example, considers it negligible noting that gene flow of favorable alleles across a broad, two-dimensional habitat may not slow divergence; speciation between populations in geographic contact is then almost as easy as between those completely isolated from each other.

I now move to closer examination of just a few current topics in phylogeography, hybridization, and speciation in birds. The choice of topics discussed, while perhaps eclectic, is designed as an entrée to the explosively burgeoning literature. Cited examples will illustrate research already done or how different findings from across the globe often make similar or even sometimes contrasting points and I hope they will stimulate further research.

\subsection{Some General Observations from Avian Phylogeography: Historical Population Size Changes and Introgression}

A recurrent finding in many phylogeographic studies has been the genetic footprint of major reductions in population size, i.e., to refugia, at the Last Glacial Maximum (LGM) 20,000 years ago followed by population (and presumably geographical range expansions) since then. This has been particularly common in European (Hewitt 1999) and North American studies (Boulet and Gibbs 2006; Friis et al. 2016) where widespread glaciation was the driver and even in Antarctica (Younger et al. 2015). Similar patterns in Australia are commonly found, but due to widespread cold, windy aridity at the LGM, not glaciation (Joseph and Omland 2009; Toon et al. 2010; Kearns et al. 2011). It is not a universal result, however. The Australian Grey Butcherbird Cracticus torquatus evidently expanded at the LGM and hybridized with a non-sister species, the Silver-backed Butcherbird C. argenteus (Kearns et al. 2014; see also Dong et al. 2017). Still other studies show important changes in population size having occurred before the LGM (in Brazil, BatalhaFilho et al. 2012; in Africa, Bowie et al. 2006; in Australia, Chan et al. 2014). A distinction to make here is that the species involved usually evolved earlier, in the Pliocene at least, whereas the Pleistocene molded their present-day diversity. This has been stressed in Africa (Voelker et al. 2010) and in the lowland Neotropical rainforests (Smith et al. 2014a, b) where dispersal and differentiation superimposed on earlier, large-scale landscape events such as the uplift of the Andes has been a major driver of avian speciation (see also Ribas et al. 2012). To complicate things, very recent speciation (middle Pleistocene onward) appears to have occurred too in North America, Europe, and Australia (Toews and Irwin 2008; Dolman and Joseph 2016; Friis et al. 2016). The point here is that the interplay between speciation before and sometimes during the Pleistocene relative to the role of the Pleistocene in shaping present-day genetic diversity within species is complex and idiosyncratic. 
Introgression repeatedly emerges from phylogeographic data. Introgression during divergence of populations and species from their common ancestor is clearly a pervasive phenomenon (reviews in Rheindt and Edwards 2011; Edwards et al. 2016; Ottenburghs et al. 2017). The application of coalescent theory in population genetics has been instrumental here. By this approach, genetic diversity within a species is traced back in time to where it coalesces in a common ancestor. This is contrasted with the gene frequency-based approach of classical population genetics. Peters et al. (2007) were perhaps the first to use coalescence in detecting ancient introgression ( $\sim 14,000$ years ago) in birds. They detected the widespread occurrence and high frequency of mtDNA more typical of one species, the Asian Falcated Duck Anas falcata, in another more widespread species, the Gadwall A. strepera of the broader Holarctic. Peters et al. (2007) were perhaps the first to use coalescence theory in birds to carefully distinguish between the two reasons why two or more present-day species can share genetic diversity. One reason is that the different species have hybridized. The other reason, which they rejected, but which is often the favored explanation of such data, is that they still share much of their common ancestor's genetic variation. That is, unlike say plumage that we can readily see as diagnostic between two species and which can evolve rapidly under natural selection, the genetic marker being studied may evolve at a slower and probably more clock-like rate and so has not yet had time to "catch up" with the more visible species-specific markers of plumage. This phenomenon is termed incomplete lineage sorting (Joseph et al. 2006, e.g., in Artamus woodswallows). In a further study of ducks (Peters et al. 2014) as well as in many other papers in avian phylogeography (Degnan 1993), it has become clear that while mtDNA will always be a useful marker to include in a phylogeographic study, it can mislead, if not carefully interpreted. We will see further examples of this elsewhere in the chapter.

Phylogeographic studies also can detect the difference between recent and current hybridization and past gene flow. Recent hybridization will be characterized by firstgeneration (F1) hybrids and backcrosses between them and the parental types. Examples come from Manthey and Robbins (2016) showing hybridization likely due to recent anthropogenic disturbance. Older hybridization will lead to more complicated patterns of admixture (e.g., Manthey et al. 2012) as we will see elsewhere in the chapter. Warranting mention here is the "ghost of gene flow past." An example comes from Australia's Western Grasswren Amytornis textilis. Most of this species' populations in the west of the Australian continent are extinct but known from museum specimens. Austin et al. (2013) detected a divergent outlier in the mtDNA diversity of the eastern Australian subspecies A. $t$. myall. This result would have remained enigmatic were it not for the availability of museum specimens of the extinct western populations, which shared this form of mtDNA. Coupled with subfossil evidence of the species having been more continuously distributed in the past and indeed ecological data, Austin et al. (2013) concluded that they had detected evidence of past gene flow prior to the extinction of the western populations. 
(A) mtDNA control region

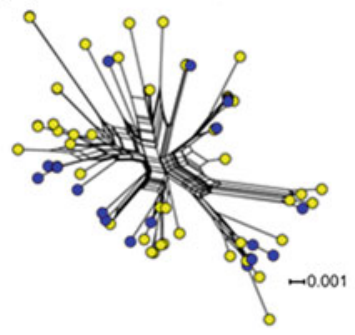

(B) 17 autosomal loci

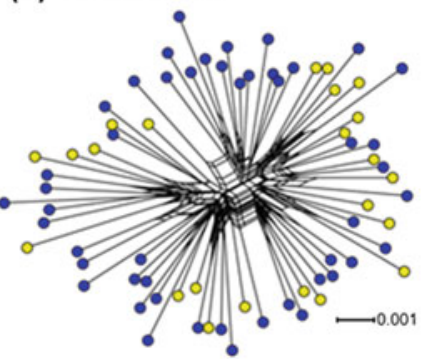

(C) 7 Z loci

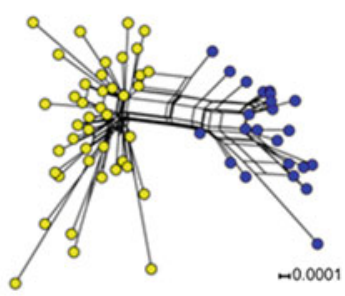

Fig. 10.2 Networks of DNA sequence diversity from Dhami et al. (2016) showing contrasting patterns in Grey Teal Anas gracilis (each yellow circle is one individual) and Chestnut Teal A. castanea (blue circles). The networks are derived from DNA sequences obtained from (a) the mtDNA control region, (b) 17 autosomal loci, and (c) $7 \mathrm{Z}$ loci. Note how only in the $\mathrm{Z}$ chromosome sequences do the two species "pull apart"

\subsection{Phylogeography, Sex Chromosomes, and Speciation}

Phylogeographic studies of two closely related Australian ducks, the sexually monomorphic Grey Teal Anas gracilis and sexually dimorphic Chestnut Teal A. castanea, lead us neatly, if surprisingly, to a consideration of sex chromosomes in speciation. Initial phylogeographic and systematic studies of genetic diversity within and between these two species found no differences between them, whether studied with allozymes (Sraml et al. 1996), mtDNA (Joseph et al. 2009), or multilocus DNA (Dhami et al. 2013). Geographic structure in one species, A. castanea, was apparent between eastern and western Australia. Insights into the birds' evolution and speciation were gained nonetheless. For example, the species had only recently diverged from their common ancestor, divergent selection best explaining their obvious differences in ecology and life history. Incomplete lineage sorting was the favored explanation of their shared diversity. But where in the genome were the genetic differences between the two species of teal?

An answer came when loci on the $\mathrm{Z}$ sex chromosome of the two teal were sequenced (in birds, males are ZZ and females ZW; Dhami et al. 2016; Fig. 10.2). Differences between the two species were immediately apparent: All Chestnut Teal $\mathrm{Z}$ chromosome sequences were more closely related to each other than any were to the Grey Teal $\mathrm{Z}$ chromosome sequences and vice versa. The $\mathrm{Z}$ chromosome has repeatedly emerged as the site of many and sometimes key important genetic differences especially those controlling reproductive isolation between closely related species. We briefly address why this is so while acknowledging that the $\mathrm{Z}$ chromosome will not necessarily reveal all in every case.

Novel mutations on sex chromosomes are directly exposed to selection in the sex having only one of each sex chromosome-XY males in mammals such as humans and ZW females in birds. Selection is therefore expected to act faster on sex chromosomes and to fix some types of beneficial mutations (Charlesworth et al. 
1987). This is the basis of fast- $X$ evolution or fast- $Z$ evolution in birds (see Ellegren 2009). It helps explain Haldane's rule (Haldane 1922; Carling and Brumfield 2008), which states that the heterogametic sex (females in birds) suffers adverse fitness consequences in hybridization. Population genetics theory also predicts more rapid accumulation of genetic divergence on the $\mathrm{Z}$ relative to autosomes because of its smaller population size promoting genetic drift.

Examples of Z-linked loci being important in tracking and driving speciation and evolution in birds include European nightingales Luscinia spp. (Storchová et al. 2009) and Ficedula flycatchers (Ellegren et al. 2012), North American Anas ducks (Lavretsky et al. 2015), Passerina buntings (Carling and Brumfield 2008, 2009), Certhia treecreepers (Manthey and Spellman 2014; Manthey et al. 2016), and in a comparative analysis of meliphagoid birds across hybrid zones in northeastern Australia (Peñalba et al. 2017) to name just a few. We should also consider physical rearrangements of entire blocks of chromosomes called chromosomal inversions. These involve an entire section of a chromosome being physically inverted. The genes in these inversions are generally inherited intact. This is because inversions hinder efficient recombination or crossing over between members of a pair of chromosomes during meiosis, which forms gametes. Inversions therefore lock up favorable combinations of genes. Chromosomal rearrangements have been more extensive on the $\mathrm{Z}$ chromosome relative to the rest of the genome (with notable exceptions such as one part of Chromosome 1A). This has been elegantly shown by Kawakami et al. (2014) in a comparison between two species with reasonable genomic data, the Australian Zebra Finch Taeniopygia guttata and the European-breeding Collared Flycatcher Ficedula albicollis (Fig. 10.3; see also van Doren et al. 2017).

Hooper and Price $(2015,2017)$ found that the number of inversion differences between closely related species is consistently predicted by whether their geographical ranges overlap and the extent of that overlap and illustrated this neatly in estrildid finches. Geographical range overlap in and of itself is not an absolute predictor of inversion differences, however. For example, there are no such differences between Collared and Pied Flycatchers Ficedula albicollis and F. hypoleuca, respectively (Backström et al. 2010a). Nonetheless, those two species have diverged at seven Z-linked loci significantly more than expected under neutrality; two of the detected candidate regions contain genes that are associated with plumage coloration in birds (Backström et al. 2010b). Indeed, the four black-and-white Ficedula flycatcher species (the other two being $F$. speculigera and $F$. semitorquata) show greater genetic divergence on the $\mathrm{Z}$ chromosome than on the autosomes. This has been attributed most simply to a fast-Z phenomenon (Sætre and Sæther 2010; Hogner et al. 2012).

Hooper and Price $(2015,2017)$ also reported variable rates of fixation of inversions across the autosomes, but inversions are more likely to be fixed on the $\mathrm{Z}$ chromosome than the average autosome. A role for gene flow in divergence is seen here. Gene flow on secondary contact between partially reproductively isolated forms may promote the spread of an inversion and its favorable combination of genes. Hooper and Price (2015) note that, because Z-linked genes diverge in function more rapidly than autosomal genes, so at any time before reproductive isolation is complete, an inversion on the $\mathrm{Z}$ chromosome should be more likely to 

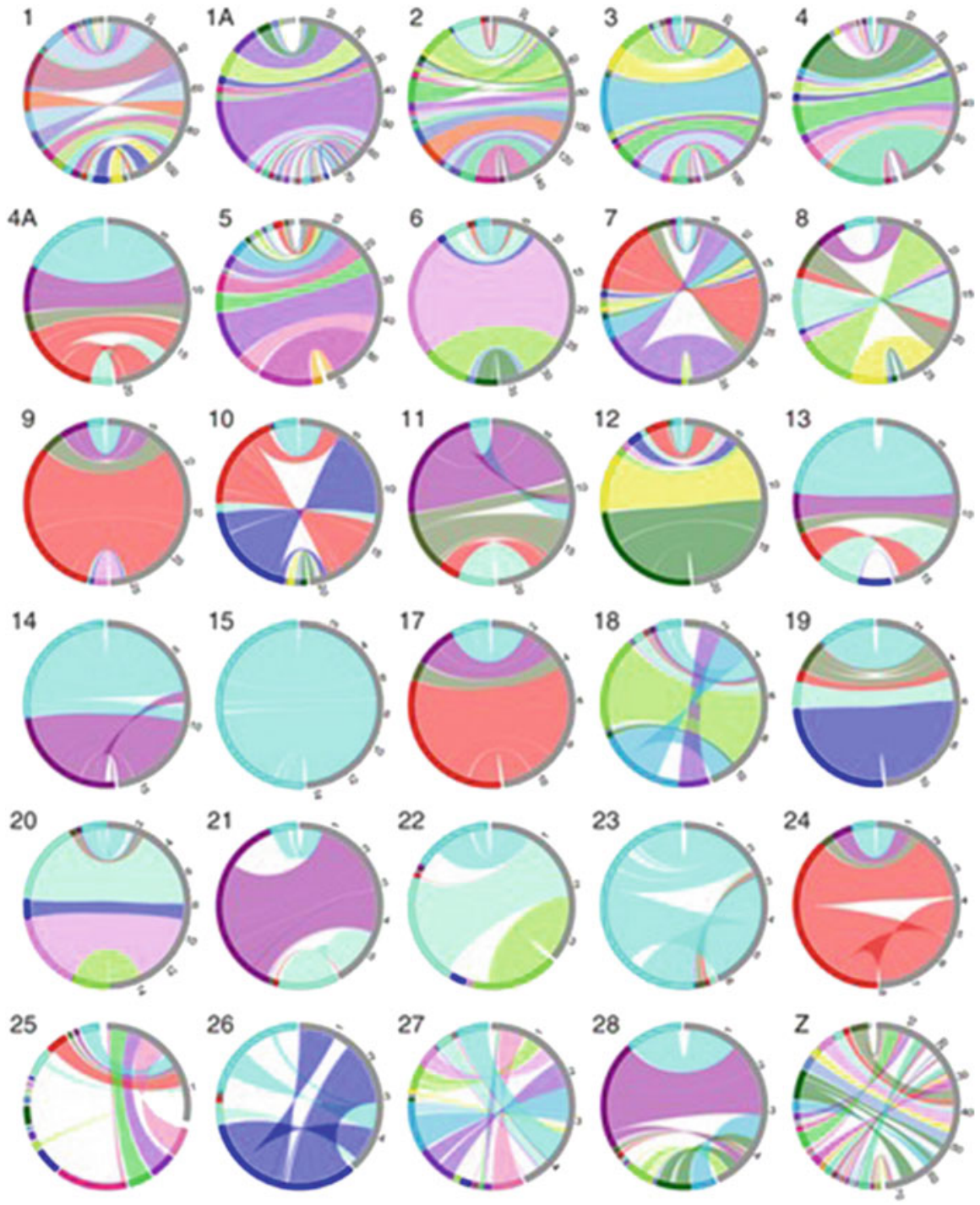

Fig. 10.3 From Kawakami et al. (2014) showing comparative circular visualization of the organization of blocks of loci on homologous chromosomes in the Collared Flycatcher Ficedula albicollis and Zebra Finch Taeniopygia guttata. Each circle represents a chromosome as numbered. Each circle's left half represents the Collared Flycatcher and the right half represents the Zebra Finch. Very little structural rearrangement has happened on some chromosomes since these two species diverged from their common ancestor, e.g., chromosomes 4 and 15, whereas far greater rearrangements have occurred in one region of chromosome $1 \mathrm{~A}$ and along the entire $\mathrm{Z}$ chromosome. Scale is indicated on the Zebra Finch side of plots, in megabases 
capture two or more alleles locally adapted-either to that population's habitat or genomic background-than an inversion on an autosome. They reason that inversions on the $\mathrm{Z}$ may be more strongly selected for, if gene flow is an important mechanism driving their selective advantage. Ornithologists should heed a most informative example of the role of hybridization spreading an inversion and promoting an adaptive radiation in Heliconius butterflies of South America (Dasmahapatra et al. 2012).

This brings us back to the two Australian teal and why the $\mathrm{Z}$ chromosome and its genes warrant attention in speciation genomics. At least for Ficedula flycatchers, the reasons have been neatly summarized by Sæther et al. (2007), Qvarnström and Bailey (2009), and Nater et al. (2015). The Z chromosome is a known location of species-specific male plumage traits and genes causing low hybrid fitness (indicated by an intronic marker in Passerina buntings; Carling and Brumfield 2008, 2009). Limited introgression of genes on it and limited recombination along its length keep blocks of genes together despite hybridization, suggesting that it is a hotspot for sexual traits in adaptive speciation where male signals and female preferences to those signals remain linked despite gene flow. These are points one can easily imagine applying in the case of the Australian teal where one member of the pair, A. castanea, is sexually dimorphic and the other, A. gracilis, is not.

\subsection{Bird Species with No Known or Very Few Genetic Differences}

Other pairs of closely related birds stand out either for still unknown location of genetic differences or for the small number of loci that appear to be involved (see also Nosil and Feder 2012; Faust-Stryjewski and Sorenson 2017 in Australo-Papuan Lonchura finches). Key examples follow. Hybridization between Blue-winged and Golden-winged Warblers Vermivora cyanoptera and V. chrysoptera, respectively, of North America, has been extensively studied with a view to clarifying their taxonomic status as species or subspecies. They seem to differ genetically at just six regions in their genome, each of which contains genes likely to be involved in feather patterning and pigmentation (Toews et al. 2016b). Hybridization appears to be a long-term feature of their evolutionary history, as also reported in an endangered subspecies of the Australian Yellow-tufted Honeyeater Lichenostomus melanops cassidix and the more common parapatric subspecies L. melanops gippslandicus (Pavlova et al. 2014). In another thoroughly studied case of hybridizing European birds, the Carrion and Hooded Crows Corvus corone and C. cornix, respectively, genomic differences appear to be concentrated in one relatively small region of one chromosome. This is likely a chromosomal inversion and involves genes controlling plumage differences (Poelstra et al. 2014), the details of which in terms of gene expression and biochemical pathways have been elucidated (Poelstra et al. 2015). Finally, the genomes of three Holarctic redpoll finches Acanthis spp. appear largely 
undifferentiated (Mason and Taylor 2015), and speciation in isolation followed by secondary contact can confidently be eliminated. Differences between the apparent species may be due to differences in gene expression related to the phenotypic differences in what is still one variable lineage.

\subsection{Hybrid Zones: A Closer Look}

\subsubsection{Suture Zones and Multiple Hybrid Zones}

Hybrid zones are regions where two well-differentiated taxa interbreed or hybridize (Barton and Hewitt 1981). Having had a similarly long history of research in ornithology (Ford 1974), they have been argued to indicate, at a minimum, that the speciation process is incomplete or may never be complete (Coyne and Orr 2004). Increasingly, porous, "leaky" genetic boundaries between clearly well-differentiated taxa, which nonetheless remain well-differentiated despite such porosity, appear to be the norm (Chan and Levin 2005; Bay and Ruegg 2017; Chattopadhyay et al. 2017; Griffith and Hooper 2017; McLean et al. 2017a, b; Slender et al. 2017). Worth stressing here is that hybrid zones are not black holes from which genes never emerge; they are evolutionary conduits through which adaptive and neutral markers can differentially move (Brumfield et al. 2001; Gompert et al. 2017).

A special opportunity to study speciation is provided by suture zones (Remington 1968, but see Swenson and Howard 2004), regions where species pairs variously either have hybrid zones, or come into close contact, or replace each other on either side of the zone while not occurring within it. Typically, there will be a range of taxonomic divergence associated with these zones from undifferentiated populations on either side through to clearly differentiated allopatric species. These zones are ideal natural experiments in which to apply genomic tools in the study of how divergence and reproductive isolation evolve. Essentially a maturing of comparative rather than single species phylogeography (Bermingham and Moritz 1998), genomic study of these zones informs how gene flow affects divergence of populations that have evolved under shared environmental history (Winger 2017; Winger and Bates 2015; Peñalba et al. 2017; Fuchs and Bowie 2015). Although much has been learned from studies of birds in several such zones using earlier mtDNA and multilocus approaches (e.g., Carpentarian, Nullarbor and Eyrean Barrier regions in Australia Balakrishnan et al. 2010; Dolman and Joseph 2012, 2016), I acknowledge the surge of this kind of genomic work in birds and in many nonavian groups and regions (e.g., Edwards et al. 2016; Gompert et al. 2017). They show how modern genomic tools are bringing entirely new levels of resolution to our understanding of the details of speciation in allopatry, parapatry, and sympatry. By studying different parts of the genome (autosomes vs. sex chromosomes vs. mtDNA), they also build on some seminal earlier work showing differential patterns of introgression among loci in North American Passerina buntings (Carling et al. 2010) and identifying genomic 
regions contributing to speciation or adaptive introgression (Borge et al. 2005; Gompert et al. 2017).

At the time of writing, foundational results from two such studies are emerging. One is from the Marañon Valley in Peru (Winger 2017; Winger and Bates 2015) and the other from tropical northeastern Australia where an especially complex set of three zones occurs (Peñalba et al. 2017; Ford 1986, 1987). I briefly review them and then examine the finer detail emerging from single species studies.

Both studies found that stronger plumage divergence (measured spectrophotometrically in Peru or through a proxy of taxonomic rank from Schodde and Mason's 1999 review in Australia) is associated with deeper genetic divergence. In the Peruvian case, this was further argued to be likely due to geographic isolation for up to two million years (Winger and Bates 2015), consistent with conventional allopatric speciation theory. Z chromosome loci were most divergent in the Australian case at least. This further supports the role of sex chromosomes in the study of speciation and the utility of using different marker sources for reconstructing evolutionary history. Conversely, lineages lacking plumage divergence across the same geographic barriers have been more recently isolated or exhibit a signature of genetic introgression after formerly isolated populations came into contact. This indicates that gene flow will impede divergence in phenotypic traits important to speciation and that evolutionary outcomes of cycles of isolation and divergence are indeed sensitive to how long gene flow is stopped. Morphometric trait evolution showed greater idiosyncrasy in both studies and so was a poor predictor of genetic divergence.

These comparative studies within regions both indicate which phenotypic traits can be predicted to diverge. In the Australian study, an additional variable of habitat (rainforest vs. mangrove vs. woodland) was included. After taxonomic rank, habitat was the next strongest predictor of genetic divergence (Peñalba et al. 2017). Together these studies undoubtedly affirm some long held if informally stated convictions among ornithologists that plumage divergence predicts genetic divergence. The full analyses of the data sets reveal that this is far from absolute, both studies finding several major divergences between essentially undifferentiated populations regarded as consubspecific. Peñalba et al.'s (2017) case of the Dusky Myzomela Myzomela obscura especially warrants further study.

\subsubsection{Detail Emerging from Single Species and Hybrid Zones: Three Case Studies}

Work on birds has been instrumental in showing how genomic tools can vastly refine our knowledge of how hybridization, hybrid zones, and phylogeography inform our understanding of speciation. The hybrid zone between two Central American manakins, White-collared Manacus candei and Golden-collared Manakin M. vitellinus, has long been a landmark example. Earlier work established discordance among geographical clines in molecular markers and plumage traits. Differential introgression of the 
M. vitellinus yellow collar across the hybrid zone was driven by sexual selection (Parsons et al. 1993; Brumfield et al. 2001; McDonald et al. 2001). Parchman et al. (2013) took the study further. They tested alternative models concerning whether adaptively important genes involved in reproductive isolation cluster in discrete "islands" in the genome or are scattered through the genome (see Cruickshank and Hahn 2014). Their data comprised 59,100 SNPs, single sites in the genome where there is variation in the DNA sequence between two populations under study. These sites were then mapped to a draft of the Manacus genome to determine in which genes they fell. Finding that genetic regions involved in adaptive divergence and reproductive isolation are scattered throughout the genome, they also concluded that many relevant loci had signatures of strong genetic differentiation and introgression. This is consistent with the hypothesis that loci involved in isolation are often characterized by a history of divergent selection and have not just drifted to differentiation.

A further case is especially valuable, because it integrates so much biological and genetic data to link a species' deeper history to biological drivers of more recent patterns in gene flow. It epitomizes how phylogeography, hybridization, speciation, and ongoing divergence are intertwined as claimed at this chapter's outset. The Red-backed Fairywren Malurus melanocephalus occurs in subtropical and tropical Australia. Two subspecies are diagnosed essentially by whether their dorsal color is red or orange (Schodde and Mason 1999; Fig. 10.4). The red-backed subspecies M. m. cruentatus occurs across Australia's tropical north, the orange-backed M. m. melanocephalus being in more southeastern parts of the range south of Cape York Peninsula (Fig. 10.4). Morphometric traits have likely been subject to ecological selection and simply track local environmental variation regardless of subspecies identity; ecological selection appears to have also influenced the evolution of tail length as an intrasexual signal used primarily among competing males (Baldassarre et al. 2013). The species' phylogeography was first assayed from 29 anonymous nuclear loci, six introns, and one mtDNA locus, amounting to over 15,000 base pairs per individual. The major phylogeographic disjunction in the species is within the red-backed subspecies' range west of Cape York Peninsula at the Carpentarian Barrier (Lee and Edwards 2008; CB in Fig. 10.4), and this was confirmed by later work with 2702 SNPs (Baldassarre et al. 2013, 2014; Fig. 10.5). The same later study showed that alleles for red plumage color have introgressed east across the hybrid zone following secondary contact and into the genomic background of the orange subspecies. That is, the plumage cline is displaced significantly east of the major phylogeographic break and the vast majority of the individual SNP clines (Fig. 10.5). Previous experimental work demonstrated an extra-pair mating advantage for red males (Baldassarre and Webster 2013). So it appears that, as in the manakins, sexual selection is driving asymmetrical introgression of red plumage alleles across the hybrid zone. This integration of phylogeography and superb field biology shows how sexual selection can complicate definition of taxonomic boundaries and promote gene flow, particularly at an intermediate stage of divergence.

The third hybrid zone to discuss here will lead us to an entirely new approach to speciation. It concerns three Australian rosella parrots, the Northern, Pale-headed and Eastern Rosellas Platycercus venustus, P. adscitus, and P. eximius, respectively. 


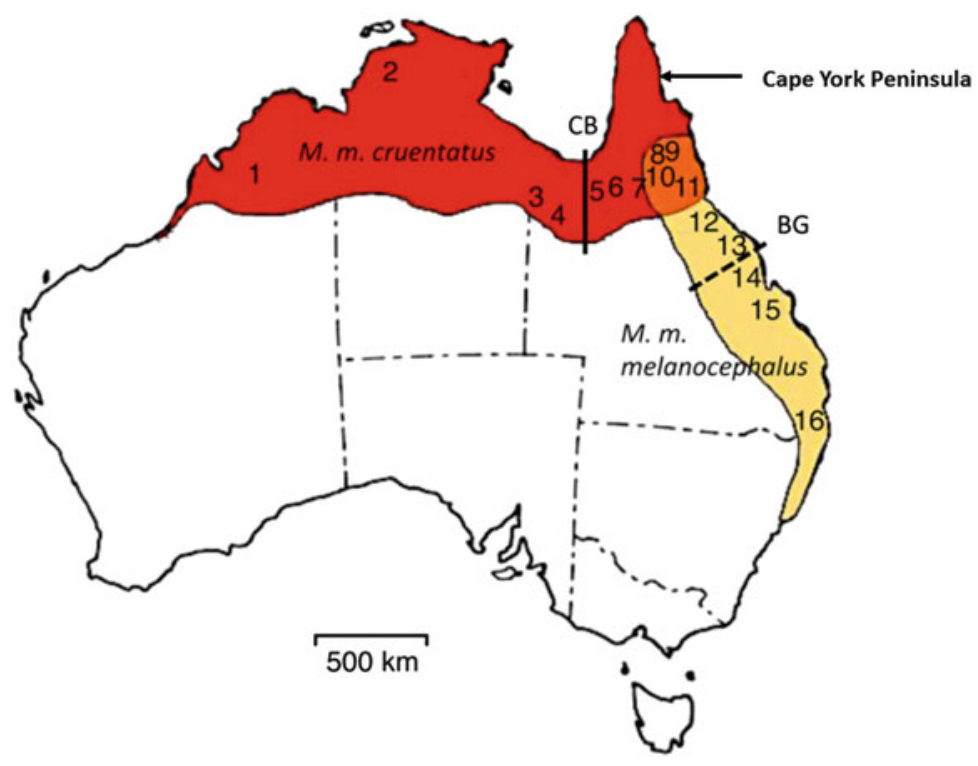

Fig. 10.4 Map modified from Baldassarre et al. (2014), showing the currently recognized distribution of the red-backed M. m. cruentatus subspecies in the west and the orange-backed $M . m$. melanocephalus subspecies in the east. The area of overlap in the northeast represents the hypothesized region of plumage overlap (Schodde and Mason 1999). The solid vertical line represents the Carpentarian Barrier (CB), and the dashed line represents the Burdekin Gap (BG). Numbers refer to sampling locations

A hybrid zone around the middle latitudes of Australia's east coast had long been recognized between $P$. adscitus and $P$. eximius. Few data and specimens were available concerning it, however, the original basis having been field observations (review in Schodde 1997). Aside from such scant information forming a basis for considering these two taxa conspecific, it was a surprise and contrary to earlier mtDNA work (Ovenden et al. 1987) when multilocus data showed $P$. adscitus and $P$. venustus to be sister species east and west, respectively, of the Carpentarian Barrier (Fig. 10.4) and that P. eximius was in turn their sister (Shipham et al. 2015). The latter study had a key twist, however. Phylogenetic analysis using mtDNA only from the Australian mainland populations of $P$. eximius leads to a finding of $P$. eximius and $P$. adscitus being sisters. Alternatively, when mtDNA from the geographically isolated Tasmanian populations of $P$. eximius is sampled, a result emerges consistent with multilocus data. Why did mtDNA within one species yield such different results?

Shipham et al. (2017) then used genomic methods to test alternative hypotheses to explain this observation. They favor the view that hybridization between $P$. eximius and $P$. adscitus has occurred and that mtDNA of $P$. adscitus has so completely introgressed southward into mainland southeast Australian P. eximius that it has completely "captured" the latter. The Tasmanian populations of $P$. eximius 


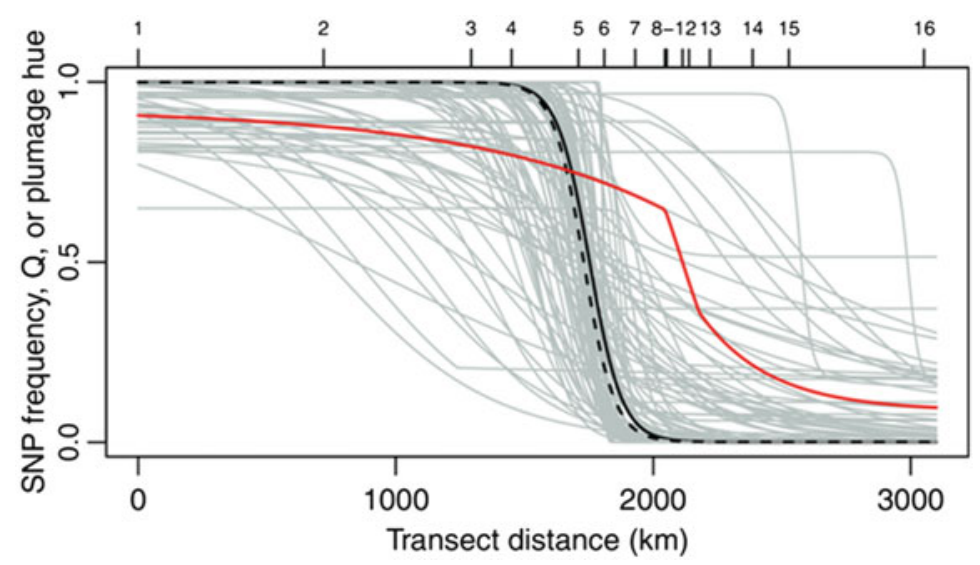

Fig. 10.5 Example from Baldassarre et al. (2014) of population genomic data increasingly being seen in studies of genomic clines across hybrid zones. Numbers along the top refer to sampling locations from west to east across northern Australia as shown in Fig. 10.4. The solid black and dashed black lines are summary geographic clines for all 2702 loci or from all 102 diagnostic loci, respectively. Clines for each of the 102 diagnostic SNP loci are shown in gray and that for plumage hue is shown in red. Higher values for hue correspond to redder dorsal plumage color in more western populations. All SNP loci have allele frequency greater than $80 \%$ on the western end of the cline and less than $20 \%$ on the eastern end, even those with very wide-fitted clines that appear to deviate from this criterion

isolated from the mainland by Bass Strait retain that species' original mtDNA. Kearns et al. (2014) found a similar case of mtDNA capture likely still progressing in Australian butcherbirds, and Dong et al. (2014) document a similar case in Taiwanese scimitar babblers Pomatorhinus spp. The problem to address next is this: Given that there are so many cases of hybridization leading to localized gene flow within and across hybrid zones, why is it that in some cases there is such an extreme outcome of the mtDNA of one form completely capturing that of another?

\subsection{Mitonuclear Incompatibility, Hybridization, and Speciation}

Mitochondria, so often called powerhouses of cells, are vital to an organism's survival. Sloan et al. (2017) note that deleterious mutations in mtDNA adversely affect energy production and that evolution has devised two solutions to this. One amounts to the mitochondrial genome of one species or population "rescuing" that of another by completely replacing it (e.g., Drovetski et al. 2015), through hybridization, with more selectively fitter, foreign mtDNA. This is adaptive introgression (Borge et al. 2005; Bonnet et al. 2017) and recalls the idea in my Introduction that hybridization involves an invasion of one genome by another. It likely explains the 
rosella and butcherbird data described above, but experimental work is of course required to test that.

Evolution's other solution to deleterious mtDNA mutations lies in the nuclear genome. Production of energy by a smoothly functioning mitochondrion requires proteins encoded by the nuclear as well as the mitochondrial genomes. Some 1500 proteins with mitochondrial function are encoded by nuclear genes and 180 of these nuclear-encoded proteins tightly cofunction with proteins encoded by mtDNA genes (Hill 2017; Sunnucks et al. 2017). Mutations in the nuclear genome can therefore lead to potentially fitter combinations of mitochondrial and nuclear genes. Different coadapted mitonuclear genotypes can evolve and lead to incompatibilities within a species; these can then evolve as isolating mechanisms (Hill 2017).

The second of these evolutionary solutions warrants more discussion. It has been developed into a mitonuclear species concept in ornithological literature by Hill (2017 and references therein). The process that generates energy, oxidative phosphorylation, cannot function, and an organism cannot survive, unless the cofunctioning mitochondrial and nuclear gene products needed for oxidative phosphorylation are in step. Tight cofunctioning of nuclear and mitochondrially encoded genes underpins the mitonuclear species concept. As mtDNA evolves faster than the nuclear genome, there must be perpetual coevolution of the two genomes. One can think of species having uniquely coadapted mitonuclear genotypes. Once populations diverge for this genotype, there will be reduced fitness of offspring due to mitonuclear incompatibilities. That mitochondrial genotype, Hill (2017) argues, becomes the best current method for diagnosing species. Does this mean that Eastern and Pale-headed Rosellas are the same species? Hill's (2017) concept may be taken to argue "yes," but recall that Northern and Pale-headed Rosellas are closest relatives. One would have to treat all three as conspecific. One could, but is it a useful taxonomy? This shows that different ways of diagnosing species usually always have some merit but can be in conflict with each other.

Whatever the mitonuclear concept's strengths and weaknesses, and Hill's (2017) discussion is well balanced with examples challenging the concept, it is a refreshingly compelling one. It prompts us to think differently about existing datasets. For example, the Eastern Yellow Robin Eopsaltria australis of Australia exhibits a geographically structured intraspecific mtDNA divergence of $6 \%$, a magnitude usually seen between genera of birds, not within a species (see Dai et al. 2017 for another example in China). This mtDNA divergence is geographically organized east-west across the bird's range (Pavlova et al. 2013). Nuclear DNA markers are organized north-south, perpendicular to the mtDNA structure. Conventional explanations of genetic drift and neutral evolution have been eliminated in explaining this pattern (Pavlova et al. 2013). A case has been built arguing that natural selection at the level of proteins encoded by the mtDNA and driven by adaptation to different climates has determined the mtDNA structure (Morales et al. 2015, 2017a). Further, adaptive mitochondrial introgression and selection against incompatible mitonuclear combinations are likely involved (Morales et al. 2017b). Finally, genomic scans (Morales et al. 2017c) show that genetic differentiation between the two adjacent but climatically divergent mtDNA lineages in this species is mostly limited, not only to 
the mitochondrial genome but also to a large part of chromosome 1A, very possibly in an inversion. This part of chromosome 1A contains tightly linked genes having mitochondrial functions. Notably, a second region of divergence is on the $\mathrm{Z}$ chromosome, suggesting that nuclear gene flow occurs primarily via male hybrids, in accordance with Haldane's rule. These findings suggest not so much that there are two species within the Eastern Yellow Robin but that mitonuclear coevolution has been critical in climatic adaptation during population divergence within the species.

Before leaving mitonuclear incompatibility, I revisit the $\mathrm{Z}$ chromosome's role in speciation. The mitonuclear concept predicts that at least some nuclear-encoded genes for proteins of mitochondrial function should be located on the $\mathrm{Z}$ chromosome. This is because in female birds the paternal $\mathrm{Z}$ chromosome must cofunction with the maternal mtDNA. The prediction is supported in the Eastern Yellow Robin and in other species such as Gouldian Finches Erythrura gouldiae (Pryke and Griffith 2009).

\subsection{Ring Species as a Special Case of Divergence with Gene Flow: Are There Any Surviving Examples?}

A theme of current speciation research emphasized in this chapter is that populations and species can diverge despite the reticulation caused by ongoing gene flow. A specific example is Mayr's (1942) ring species concept (Fig. 10.6). This posits that an ancestral population spreads in a geographical ring away from its origin. Eventually, populations at the beginning and end of the ring are in contact and behave as separate species reproductively isolated from each other in sympatry. The hypothesis makes very specific predictions about patterns of genetic diversity that should be recoverable. In ornithology at least, these predictions have not survived such testing with genetic data or even with retrodictive modeling of paleodistributions. Consequently, more conventional alternative explanations of speciation in allopatry followed by range expansion leading to secondary contact cannot be rejected. They explain the data as well if not better than the ring species hypothesis. Examples are the Herring Gull Larus argentatus complex of Northern Hemisphere circumpolar regions (Liebers et al. 2004), the Crimson Rosella Platycercus elegans complex of southeastern Australia (Joseph et al. 2008; Fig. 10.6), and the Greenish Warbler Phylloscopus trochiloides complex encircling Tibet (Alcaide et al. 2014; Peterson and Anamza 2017). The point here is not that the ring species hypothesis should be abandoned but that it continues to engender stimulating evolutionary insights into the details of speciation in each case (e.g., Mihailova et al. 2014; Irwin et al. 2016). 
(a)

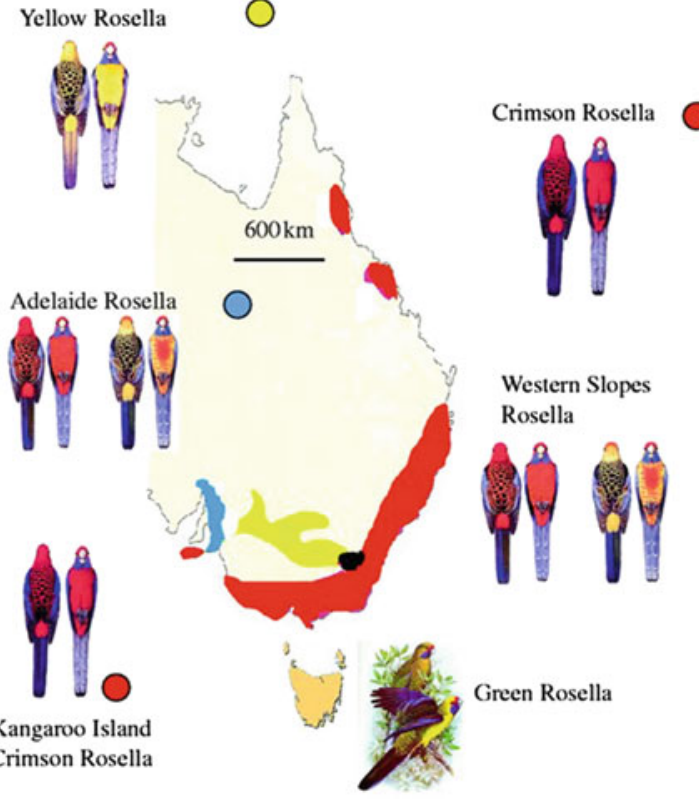

(b)

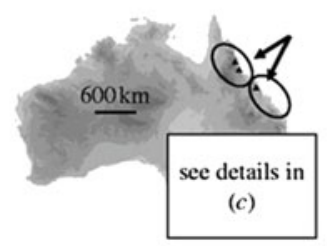

(c)

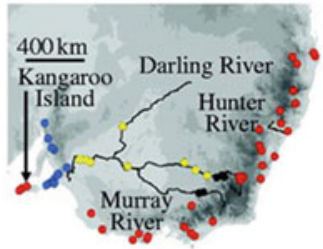

Fig. 10.6 Example of a putative ring species, not supported as such by genetic analysis from Joseph et al. (2008): (a) Distribution and plumage phenotype variation in parrots of the Crimson Rosella complex in eastern Australia (from Forshaw and Cooper (2002) in this and subsequent figures). Note the narrow zone of unsuitable habitat currently separating Adelaide and Yellow. (b, c) Sampling scheme of vouchered museum specimens for mtDNA analyses of the full mainland distribution of the complex

\subsection{Hybrid Species}

Can hybridization lead to the evolution of new species in birds? A now well-studied case is that of the Italian Sparrow Passer italiae. Long hypothesized to be of hybrid origin because of male plumage traits intermediate between House Passer domesticus and Spanish Sparrows P. hispaniolensis, its hybrid origin is confirmed by extensive nuclear and mitochondrial genetic work as well as ecological and behavioral studies (Elgvin et al. 2011; Hermansen et al. 2011; Trier et al. 2014; Sætre et al. 2017). Z-linked and mitonuclear reproductive barriers limit gene flow and maintain the integrity of the three populations (Trier et al. 2014). Hill (2017) notes it as a case in which a novel but adaptive combination of genes for mitochondrial and nuclear-encoded proteins arose through hybridization. Postzygotic selection against mitonuclear incompatibilities now limits gene flow between the three populations (Trier et al. 2014). Italian Sparrows have come into secondary contact with Spanish Sparrows from which they have diverged significantly across 81 protein-coding genes (Sætre et al. 2017). Six of these genes showing the greatest divergence are associated with learning and neural development in other bird species suggesting a role for behavioral isolating mechanisms. Prezygotic assortative mating 
may also contribute to the maintenance of coadapted mitochondrial and nuclear genes (Hermansen et al. 2011).

House and Spanish Sparrows have also hybridized across the Mediterranean in North Africa but with outcomes differing in terms of which mtDNA alleles are most frequent in hybrids (Belkacem et al. 2017). Clearly, much remains to be learned (see also Brelsford et al. 2011 for the case of Audubon's Warbler Setophaga auduboni). Importantly, other cases where two species interact differently at different zones of contact offer rich potential for study. Prime examples have been studied in European populations of Barn Swallows Hirundo rustica (Scordato et al. 2017) and North American Mountain Chickadees Poecile gambeli (Manthey et al. 2012). Much remains to be learned in Australia in the Crimson Rosella group (Joseph et al. 2008) and Brown and Inland Thornbills Acanthiza pusilla and A. apicalis (Black et al. 2015). A special case warranting an entire chapter is the role of hybridization in driving the history of one of the most famous examples of adaptive evolution, Darwin's finches (see Grant and Grant 2016 and references therein and for alternative views McKay and Zink 2014).

\subsubsection{Hybrid Zones Sometimes Move}

Although on evolutionarily short time scales of centuries and decades, data are now available to show that some hybrid zones have moved and some have not (MoralesRozo et al. 2017). Insights gained from this phenomenon vary. Long-term study of North American birds provides the richest examples. In Sphyrapicus sapsuckers, Billerman et al. (2016) used climatic models to accurately recover the hybrid zone's shift, which was itself documented with museum specimens collected over the last 100 years. They predicted future trends in the ranges of the respective parental taxa and that the climatic niche of the hybrids will disappear under climate change. Similarly in Passerina buntings, Carling and Zuckerberg (2011) suggest that continued spread of the hybrid zone threatens one of the parental species. In Poecile chickadees, Taylor et al. (2014) found a set of loci consistently linked to genomic regions likely under selection and linked to reproductive isolation. These loci showed patterns of elevated divergence and reduced introgression regardless of when samples were collected and despite multiple generations of admixture between the parental species. In contrast, Mettler and Spellman (2009) argued that a Pheucticus grosbeak hybrid zone had not moved in 40 years and constituted a "tension zone" maintained by a balance between dispersal into the hybrid zone and selection against hybrids. In Australia, it is unclear whether a well-studied hybrid zone between forms of the Australian Magpie Gymnorhina tibicen maintained by selection (Hughes et al. 2001) is stationary or moving (Burton and Martin 1976). 


\subsection{A View to the Future}

This chapter has skimmed the surface of the vast body of published work accruing almost daily on the genetic and genomic details of phylogeography, hybridization, and speciation of the world's birds. Genomic data are bringing much to our understanding of evolutionary history within and among species. As with any mature field, our understanding has reached a point where we appreciate well the theoretical problems still to be addressed and how data now obtainable from genomic methods may help. Disentangling effects of selection and drift in different parts of the genome as populations diverge is one such challenge (Southcott and Kronforst 2017). In contrast, our understanding of the genetics of adaptation at the molecular level, though developing, is still a frontier. Much has been learned from certain species such as climate-driven selection in Australia's Eastern Yellow Robin (discussed above) and about the role individual genes play $[M C 1 R$ in plumage coloration (San-Jose et al. 2017; Faust-Stryjewski and Sorenson 2017); ALX1 and HMGA2 in bill morphology (Lamichhaney et al. 2015, 2016); DRD3 in evolution of migration (Chap. 7; Delmore et al. 2015)]. Floodgates are likely to open in the coming years, however, as more and more genomes are sequenced. At present, regions of the genome showing interest for one aspect or another of a bird's evolution can often be mapped to a reference genome in one of a few phylogenetically distant species for which reasonable genomic assemblies are available (e.g., the non-passerine chicken or the two oscine passerines Collared Flycatcher and Zebra Finch). This is like trying to determine one's location 3 days into a drive across a continent using a map showing approximate location of one road and no provincial boundaries or towns other than the journey's start and end points. As more annotated genomes (i.e., with genes mapped and named) come online, more and more genomic reference maps will be available across the avian tree of life. The mapping analogy would be that one knows one's whereabouts, because all roads, towns, and geographical features are shown accurately to scale. Then we will better understand either the function of genes or their proximity to genes of known function in a given study species (consider the clines in Fig. 10.5 for the Red-backed Fairywren) and so develop an understanding of how speciation occurs by truly integrating history and selection. The importance of this is neatly illustrated in the comparison of Ruegg et al. (2014) and Delmore et al. (2015) who both tried to elucidate the genetic basis to the evolution of migration in Swainson's Thrush Catharus ustulatus, the former mapping data to the Zebra Finch genome and the latter mapping to a draft assembly for Swainson's Thrush itself. This explains their different conclusions about the genes involved in the evolution of migration and how they are organized across the genome.

Byers et al. (2017) have neatly summarized these challenges. Figure 10.7, here reproduced from their paper, says it all! At the time of writing, the floodgates of genomic resources with which to study birds are about to open. Research into the evolution of birds through understanding the interplay among phylogeography, hybridization, and speciation has a bright future. 

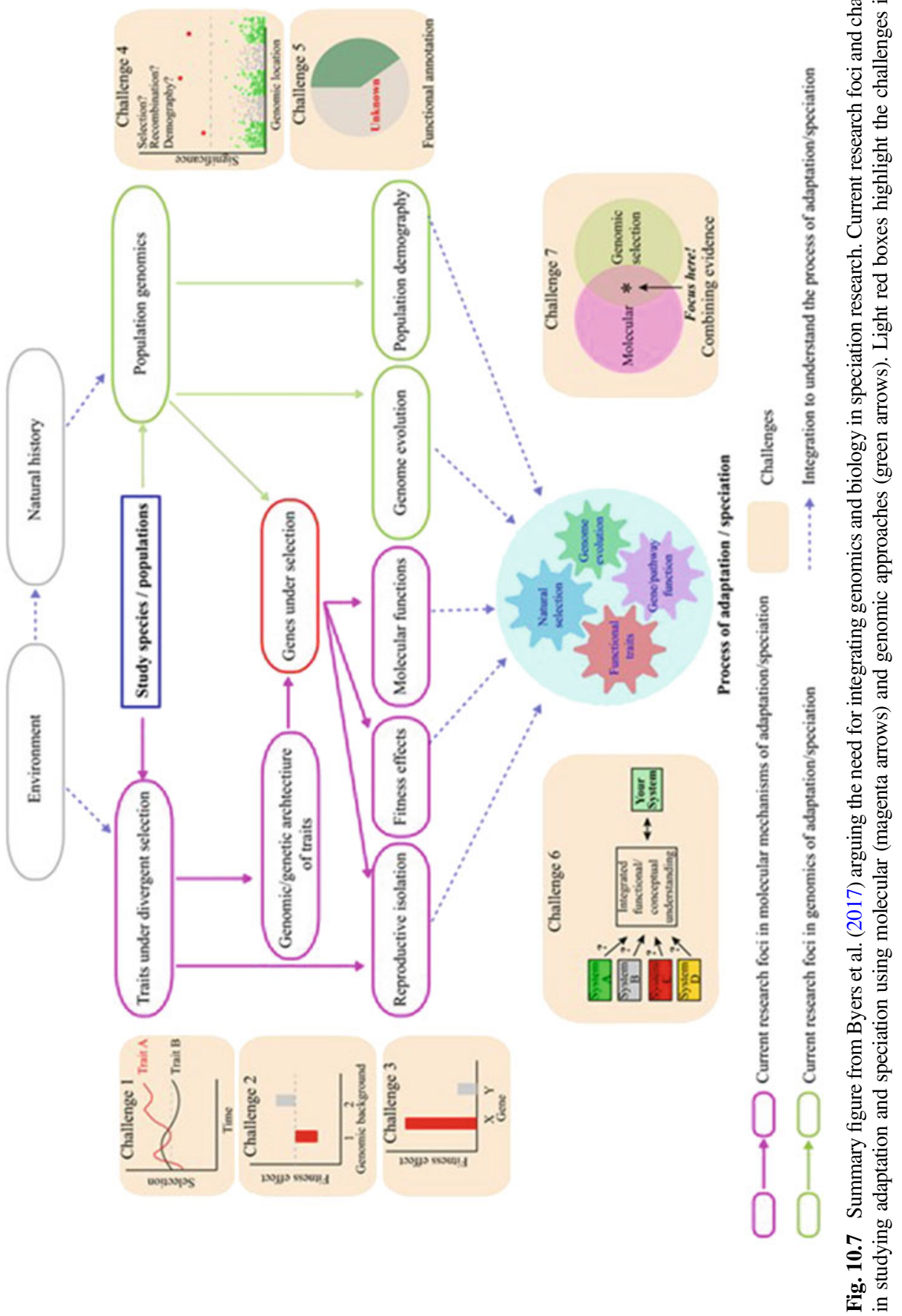

\%

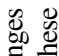

․ 
Acknowledgments I am grateful to Dieter Thomas Tietze and Darren Irwin for the opportunity to write this chapter. Joshua Peñalba and Craig Moritz have helped me find and, I hope, understand some literature that I might not have found otherwise. Andrew Black offered helpfully incisive comments to improve my expression. The manuscript was closed on 22 December 2017.

\section{References}

Abbott R, Albach D, Ansell S et al (2013) Hybridization and speciation. J Evol Biol 26:229-246. https://doi.org/10.1111/j.1420-9101.2012.02599.x

Alcaide M, Scordato ESC, Price TD, Irwin DE (2014) Genomic divergence in a ring species complex. Nature 511:83-85

Austin J, Joseph L, Pedler L, Black A (2013) Uncovering cryptic evolutionary diversity in extant and extinct populations of the southern Australian arid zone Western and Thick-billed Grasswrens (Passeriformes: Maluridae: Amytornis). Conserv Genet 14:173-1184. https://doi. org/10.1007/s10592-013-0504-9

Avise JC, Arnold J, Ball RM et al (1987) Intraspecific phylogeography: the mitochondrial DNA bridge between population genetics and systematics. Annu Rev Ecol Syst 18:489-522

Backström N, Palkopoulou E, Qvarnström A, Ellegren H (2010a) No evidence for Z-chromosome rearrangements between the pied flycatcher and the collared flycatcher as judged by gene-based comparative genetic maps. Mol Ecol 19:3394-3405

Backström N, Lindell J, Zhang Y, Palkopoulou E, Qvarnström A, Sætre G-P, Ellegren H (2010b) A high-density scan of the $\mathrm{Z}$ chromosome in Ficedula flycatchers reveals candidate loci for diversifying selection. Evolution 64:3461-3475

Balakrishnan CN, Lee JY, Edwards SV (2010) Phylogeography and phylogenetics in the nuclear age. In: Grant P, Grant R (eds) Searching for the causes of evolution: from field observations to mechanisms. Princeton University Press, Princeton, pp 65-88

Baldassarre DT, Webster MS (2013) Experimental evidence that extrapair mating drives asymmetrical introgression of a sexual trait. Proc R Soc B Biol Sci 280:20132175

Baldassarre DT, Thomassen HA, Karubian J, Webster MS (2013) The role of ecological variation in driving divergence of sexual and non-sexual traits in the red-backed fairy-wren (Malurus melanocephalus). BMC Evol Biol 13:75 http://www.biomedcentral.com/1471-2148/13/75

Fig. 10.7 (continued) research areas, as follows: Challenge 1, selection on traits might be dynamic and dependent on time; Challenge 2, the fitness effects of individual genes might be dependent on genomic background, such as epistatic interactions among genes; Challenge 3, different genes associated with traits that affect fitness might have different fitness effects, and these effects might additionally vary with environmental conditions; Challenge 4, candidate loci identified using adaptation/speciation genomics might be spurious, with significant outliers resulting from demographic changes, false positives, or selective sweeps, rather than selection on the locus itself; and Challenge 5, even in model organisms (e.g., thale cress Arabidopsis thaliana, common fruit fly Drosophila melanogaster, house mouse Mus musculus), the function of a large proportion of genes remains unknown. Two remaining challenges of an integrative approach-Challenge 6 , synthesizing results from multiple systems into a conceptual whole, and Challenge 7, combining evidence from molecular and genomic approaches-must also be addressed. The bottom circle depicts the integration of molecular and genomic approaches to studying adaptation and speciation and suggests some future integrative approaches (blue dashed arrows). See Byers et al. (2017) for further discussion 
Baldassarre DT, White TA, Karubian J, Webster MS (2014) Genomic and morphological analysis of a semipermeable avian hybrid zone suggests asymmetrical introgression of a sexual signal. Evolution 68:2644-2657

Barton NH (2013) Does hybridization influence speciation? J Evol Biol 26:267-269

Barton NH, Hewitt GM (1981) Hybrid zones and speciation. In: Atchley WR, Woodruff D (eds) Evolution and speciation. Cambridge University Press, Cambridge, pp 109-145

Batalha-Filho H, Cabanne GS, Miyaki CY (2012) Phylogeography of an Atlantic forest passerine reveals demographic stability through the last glacial maximum. Mol Phylogenet Evol 65:892-902

Bay RA, Ruegg K (2017) Genomic islands of divergence or opportunities for introgression? Proc R Soc B 284:20162414. https://doi.org/10.1098/rspb.2016.2414

Beheregaray L (2008) Twenty years of phylogeography: the state of the field and the challenges for the Southern Hemisphere. Mol Ecol 17:3754-3774. https://doi.org/10.1111/j.1365-294X.2008.03857.x

Belkacem AA, Gast O, Stuckas H, Canal D, LoValvo M, Giacalone G, Päckert M (2017) North African hybrid sparrows (Passer domesticus, P. hispaniolensis) back from oblivion - ecological segregation and asymmetric mitochondrial introgression between parental species. Ecol Evol 6:5190-5206. https://doi.org/10.1002/ece3.2274

Bermingham E, Moritz C (1998) Comparative phylogeography: concepts and applications. Mol Ecol 7:367-369

Billerman SM, Murphy MA, Carling MD (2016) Changing climate mediates sapsucker (Aves: Sphyrapicus) hybrid zone movement. Ecol Evol 6:7976-7990

Black AB, Horton P, Joseph L (2015) Diverse interactions, including hybridisation, between Brown and Inland Thornbills in South Australia. S Aust Ornithol 41:18-34

Bonnet T, Leblois R, Rousset F, Crochet P-A (2017) A reassessment of explanations for discordant introgressions of mitochondrial and nuclear genomes. Evolution 71:2140-2158

Borge T, Lindroos K, Nádvorník P, Syvänen AC, Sætre GP (2005) Amount of introgression in flycatcher hybrid zones reflects regional differences in pre- and post-zygotic barriers to gene exchange. J Evol Biol 18:1416-1424

Boulet M, Gibbs HL (2006) Lineage origin and expansion of a Neotropical migrant songbird after recent glaciation events. Mol Ecol 15:2505-2525

Bowie RCK, Fjeldså J, Hackett SJ, Bates JM, Crowe TM (2006) Coalescent models reveal the relative roles of ancestral polymorphism, vicariance, and dispersal in shaping phylogeographical structure of an African montane forest robin. Mol Phylogenet Evol 38:171-188. https://doi.org/ 10.1016/j.ympev.2005.06.001

Bowie RCK, Fjeldså J, Kiure J (2009) Multilocus molecular DNA variation in Winifred's Warbler Scepomycter winifredae suggests cryptic speciation and the existence of a threatened species in the Rubeho-Ukaguru Mountains of Tanzania. Ibis 151:709-719

Brelsford A, Mila B, Irwin DE (2011) Hybrid origin of Audubon's warbler. Mol Ecol 20:2380-2389. https://doi.org/10.1111/j.1365-294X.2011.05055.x

Brumfield R, Jernigan JW, McDonald DB, Braun MJ (2001) Evolutionary implications of divergent clines in an avian (Manacus: Aves) hybrid zone. Evolution 55:2070-2087

Burton TC, Martin AA (1976) Analysis of hybridization between Black-backed and White-backed Magpies in south-eastern Australia. Emu 76:30-36

Butlin RK, Ritchie MG (2013) Pulling together or pulling apart: hybridization in theory and practice. J Evol Biol 26:294-298

Byers KJRP, Xu S, Schlüter PM (2017) Molecular mechanisms of adaptation and speciation: why do we need an integrative approach? Mol Ecol 26:277-290

Cadena CD, Cuervo AM (2010) Molecules, ecology, morphology, and songs in concert: how many species is Arremon torquatus (Aves: Emberizidae)? Biol J Linn Soc 99:152-176

Carling MD, Brumfield RT (2008) Haldane's rule in an avian system: using cline theory and divergence population genetics to test for differential introgression of mitochondrial, autosomal and sex-linked loci across the Passerina bunting hybrid zone. Evolution 62:2600-2615 
Carling MD, Brumfield RT (2009) Speciation in Passerina buntings: introgression patterns of sex-linked loci identify a candidate gene region for reproductive isolation. Mol Ecol 18:834-847

Carling MD, Zuckerberg B (2011) Spatio-temporal changes in the genetic structure of the Passerina bunting hybrid zone. Mol Ecol 20:1166-1175

Carling MD, Lovette IJ, Brumfield RT (2010) Historical divergence and gene flow: coalescent analyses of mitochondrial, autosomal and sex-linked loci in Passerina buntings. Evolution 64:1762-1772

Chan KMA, Levin SA (2005) Leaky prezygotic isolation and porous genomes: rapid introgression of maternally inherited DNA. Evolution 59:720-729

Chan YL, Schanzenbach D, Hickerson MJ (2014) Detecting concerted demographic response across community assemblages using hierarchical approximate Bayesian computation. Mol Biol Evol 31:2501-2515. https://doi.org/10.1093/molbev/msu187

Charlesworth B, Coyne JA, Barton NH (1987) The relative rates of evolution of sex chromosomes and autosomes. Am Nat 130:113-146

Chattopadhyay B, Garg KM, Gwee CY, Edwards SV, Rheindt FE (2017) Gene flow during glacial habitat shifts facilitates character displacement in a Neotropical flycatcher radiation. BMC Evol Biol 17:210. https://doi.org/10.1186/s12862-017-1047-3

Coyne JA, Orr HA (2004) Speciation. Sinauer Associates, Sunderland, MA

Cruickshank TE, Hahn MW (2014) Reanalysis suggests that genomic islands of speciation are due to reduced diversity, not reduced gene flow. Mol Ecol 23:3133-3157

Dai C, Hao Y, Lei F (2017) The absence of reproductive isolation between non-sister and deeply diverged mitochondrial lineages of the black-throated tit (Aegithalos concinnus) revealed by a multilocus genetic analysis in a contact zone. BMC Evol Biol 17:266. https://doi.org/10.1186/ s12862-017-1114-9

Dasmahapatra KK, Walters JR, Briscoe AD et al (Heliconius Genome Consortium) (2012) Butterfly genome reveals promiscuous exchange of mimicry adaptations among species. Nature 487:94-98

de Queiroz K (2007) Species concepts and species delimitation. Syst Biol 56:879-886

Degnan SM (1993) The perils of single gene trees - mitochondrial versus single-copy nuclear DNA variation in white-eyes (Aves: Zosteropidae). Mol Ecol 2:219-225

Delmore KE, Hübner S, Kane NC, Schuster R, Andrew RL, Câómara F, Guigo` R, Irwin DE (2015) Genomic analysis of a migratory divide reveals candidate genes for migration and implicates selective sweeps in generating islands of differentiation. Mol Ecol 24:1873-1888. https://doi. org $/ 10.1111 / \mathrm{mec} .13150$

Dhami KK, Joseph L, Roshier DA, Heinsohn R, Peters JL (2013) Multilocus phylogeography of Australian teals (Anas spp.): a case study of the relationship between vagility and genetic structure. J Avian Biol 44:169-178. https://doi.org/10.1111/j.1600-048X.2012.05826.x

Dhami KK, Joseph L, Roshier DA, Peters JL (2016) Recent speciation and elevated Z-chromosome differentiation between a sexually dichromatic and monochromatic pair of Australian teals (Anatidae: Anas). J Avian Biol 47:92-102. https://doi.org/10.1111/jav.00693

Dolman G, Joseph L (2012) A species assemblage approach to comparative phylogeography of birds in southern Australia. Ecol Evol 2:354-369. https://doi.org/10.1002/ece3.87

Dolman G, Joseph L (2015) Evolutionary history of birds across southern Australia: structure, history and taxonomic implications of mitochondrial DNA diversity in an ecologically diverse suite of species. Emu 115:35-48. https://doi.org/10.1071/MU14047

Dolman G, Joseph L (2016) Multi-locus sequence data reveal Pleistocene speciation in semi-arid southern Australian birds (Cinclosoma spp.) was associated with increased genetic drift. BMC Evol Biol 16:226. https://doi.org/10.1186/s12862-016-0798-6

Dong F, Zou F-S, Lei F-M, Liang W, Li S-H, Yang X-J (2014) Testing hypotheses of mitochondrial gene-tree paraphyly: unravelling mitochondrial capture of the Streak-breasted Scimitar Babbler (Pomatorhinus ruficollis) by the Taiwan Scimitar Babbler (Pomatorhinus musicus). Mol Ecol 23:5855-5867 
Dong F, Hung C-M, Li X-L, Gao J-Y, Zhang Q, Wu F, Lei F-M, Li S-H, Yang X-J (2017) Ice age unfrozen: severe effect of the last interglacial, not glacial, climate change on East Asian avifauna. BMC Evol Biol 17:244. https://doi.org/10.1186/s12862-017-1100-2

Drovetski SV, Semenov G, Red'kin YA, Sotnikov VN, Fadeev IV, Koblik EA (2015) Effects of asymmetric nuclear introgression, introgressive mitochondrial sweep, and purifying selection on phylogenetic reconstruction and divergence estimates in the pacific clade of Locustella warblers. PLoS One 10(4):e0122590. https://doi.org/10.1371/journal.pone.0122590

Edwards SV, Potter S, Schmitt CJ, Bragg JC, Moritz C (2016) Reticulation, divergence, and the phylogeography-phylogenetics continuum. Proc Natl Acad Sci USA 113:8025-8032

Elgvin TO, Hermansen JS, Fijarczyk A, Bonnet T, Borge T et al (2011) Hybrid speciation in sparrows II: a role for sex chromosomes? Mol Ecol 20:3823-3837

Ellegren H (2009) Genomic evidence for a large-Z effect. Proc R Soc Lond B 276:361-366

Ellegren H, Smeds L, Burri R et al (2012) The genomic landscape of species divergence in Ficedula flycatchers. Nature 491:756-760

Faust-Stryjewski K, Sorenson M (2017) Mosaic genome evolution in a recent and rapid avian radiation. Nat Ecol Evol 1:1912-1922. https://doi.org/10.1038/s41559-017-0364-7

Ford J (1974) Concepts of subspecies and hybrid zones and their application in Australian ornithology. Emu 74:113-123

Ford J (1986) Avian hybridization and allopatry in the region of the Einasleigh Uplands and Burdekin-Lynd Divide, north-eastern Queensland. Emu 86:87-110

Ford J (1987) Hybrid zones in Australian birds. Emu 87:158-178

Forshaw J, Cooper WT (2002) Australian parrots, 3rd edn. Robina Press, Queensland

Friesen V (2015) Speciation in seabirds: why are there so many species... and why aren't there more? J Ornithol 156(Suppl 1):S27-S39. https://doi.org/10.1007/s10336-015-1235-0

Friis G, Aleixandre P, Rodríguez-Estrella R, Navarro-Sigüenza AG, Milá B (2016) Rapid postglacial diversification and long-term stasis within the songbird genus Junco: phylogeographic and phylogenomic evidence. Mol Ecol 25:6175-6195

Fuchs J, Bowie RCK (2015) Concordant genetic structure in two species of woodpecker distributed across the primary West African biogeographic barriers. Mol Phylogenet Evol 88:64-74

Gompert Z, Mandeville EG, Buerkle CA (2017) Analysis of population genomic data from hybrid zones. Annu Rev Ecol Evol Syst 48:207-229

Grant PR, Grant BR (1992) Hybridization of bird species. Science 256:193-197

Grant PR, Grant BR (2016) Introgressive hybridization and natural selection in Darwin's finches. Biol J Linn Soc 117:812-822

Griffith SC, Hooper DM (2017) Geographical variation in bill colour in the long-tailed finch: evidence for a narrow zone of admixture between sub-species. Emu 117:141-150

Haldane JBS (1922) Sex-ratio and unisexual sterility in hybrid animals. J Genet 12:101-109

Harvey MG, Brumfield RT (2015) Genomic variation in a widespread Neotropical bird (Xenops minutus) reveals divergence, population expansion, and gene flow. Mol Phylogenet Evol 83:305-316

Harvey MG, Seeholzer GF, Smitha BT, Rabosky DL, Cuervo AM, Brumfield RT (2017) Positive association between population genetic differentiation and speciation rates in New World birds. Proc Natl Acad Sci USA 114:6328-6333

Hermansen JS, Sæther SA, Elgvin TO, Borge T, Hjelle E et al (2011) Hybrid speciation in sparrows I: phenotypic intermediacy, genetic admixture and barriers to gene flow. Mol Ecol 20:3812-3822

Hewitt GM (1999) Post-glacial re-colonization of European biota. Biol J Linn Soc 68:87-112

Hill GE (2017) The mitonuclear compatibility species concept. Auk 134:393-409

Hogner S, Sæther SA, Borge T, Bruvik T, Johnsen A, Sætre G-P (2012) Increased divergence but reduced variation on the $\mathrm{Z}$ chromosome relative to autosomes in Ficedula flycatchers: differential introgression or the faster-Z effect? Ecol Evol 2:379-397

Hooper DM, Price TD (2015) Rates of karyotypic evolution in estrildid finches differ between island and continental clades. Evolution 69:890-903 
Hooper DM, Price TD (2017) Chromosomal inversion differences correlate with range overlap in passerine birds. Nat Ecol Evol 1:1526-1534

Hughes JM, Baker AM, de Zylva G, Mather PB (2001) A phylogeographic analysis of southern and eastern populations of the Australian magpie: evidence for selection in maintenance of the distribution of two plumage morphs. Biol J Linn Soc 74:25-34. https://doi.org/10.1006/bijl. 2001.0564

Irwin DE, Alcaide M, Delmore KE, Irwin JH, Owens GL (2016) Recurrent selection explains parallel evolution of genomic regions of high relative but low absolute differentiation in a ring species. Mol Ecol 25:4488-4507

Joseph L, Omland K (2009) Phylogeography: its development and impact in Australo-Papuan ornithology with special reference to paraphyly in Australian birds. Emu 109:1-23

Joseph L, Wilke T, Ten Have J, Chesser RT (2006) Implications of mitochondrial DNA polyphyly in two ecologically undifferentiated but morphologically distinct migratory birds, the masked and white-browed Woodswallows Artamus spp. of inland Australia. J Avian Biol 37:625-636

Joseph L, Dolman G, Saint K, Donnellan S, Berg M, Bennett A (2008) Where and when does a ring start and end? Testing the ring species hypothesis in a species complex of Australian parrots. Proc R Soc B Biol Sci 275:2431-2440. https://doi.org/10.1098/rspb.2008.0765

Joseph L, Adcock G, Linde C, Omland K, Heinsohn R, Roshier D (2009) A tangled, rampantly paraphyletic tale of two teal: population history of the Grey and Chestnut Teal of Australia. J Avian Biol 40:430-439. https://doi.org/10.1111/j.1600-048X.2008.04652.x

Kawakami T, Smeds L, Backström AN, Husby A, Qvarnström A, Mugal CF, Olason P, Ellegren HS (2014) A high-density linkage map enables a second-generation collared flycatcher genome assembly and reveals the patterns of avian recombination rate variation and chromosomal evolution. Mol Ecol 23:4035-4058. https://doi.org/10.1111/mec.12810

Kearns A, Joseph L, Omland K, Cook L (2011) Testing the impact of transient Plio-Pleistocene barriers in monsoonal Australo-Papua: did mangrove habitats maintain genetic connectivity in the Black Butcherbird? Mol Ecol 20:5042-5059. https://doi.org/10.1111/j.1365-294X.2011.05330.x

Kearns A, Joseph L, Toon A, Cook L (2014) Australia's arid-adapted butcherbirds experienced range expansions during Pleistocene glacial maxima. Nat Commun 5:3994. https://doi.org/10. 1038/ncomms4994

Lamichhaney S, Berglund J, Almén MS et al (2015) Evolution of Darwin's finches and their beaks revealed by genome sequencing. Nature 518:371-375

Lamichhaney S, Han F, Berglund J et al (2016) A beak size locus in Darwin's finches facilitated character displacement during a drought. Science 352:470-474

Lavretsky P, Dacosta JM, Hernández-Baños BE, Engilis A, Sorenson MD, Peters JL (2015) Speciation genomics and a role for the $\mathrm{Z}$ chromosome in the early stages of divergence between Mexican ducks and mallards. Mol Ecol 24:5364-5378

Lee JY, Edwards SV (2008) Divergence across Australia's Carpentarian barrier: statistical phylogeography of the red-backed fairy wren (Malurus melanocephalus). Evolution 62:31173134

Liebers D, de Knijff P, Helbig AJ (2004) The herring gull complex is not a ring species. Proc R Soc B 271:893-901. https://doi.org/10.1098/rspb.2004.2679

Mallet J (2005) Hybridization as an invasion of the genome. Trends Ecol Evol 20:229-237

Mallet J (2008) Hybridization, ecological races and the nature of species: empirical evidence for the ease of speciation. Philos Trans R Soc B 363:2971-2986

Mallet J, Besansky N, Hahn MW (2016) How reticulated are species? BioEssays 38:140-149

Manthey JD, Robbins MB (2016) Genomic insights into hybridization in a localized region of sympatry between pewee sister species (Contopus sordidulus $\times$ C. virens) and their chromosomal patterns of differentiation. Avian Res 7:6. https://doi.org/10.1186/s40657-016-0040-7

Manthey JD, Spellman GM (2014) Increased differentiation and reduced gene flow in sex chromosomes relative to autosomes between lineages of the brown creeper Certhia americana. J Avian Biol 45:149-156. https://doi.org/10.1111/j.1600-048X.2013.00233.x 
Manthey JD, Klicka J, Spellman GM (2012) Is gene flow promoting the reversal of Pleistocene divergence in the Mountain Chickadee (Poecile gambeli)? PLoS One 7(11):e49218. https://doi. org/10.1371/journal.pone.0049218

Manthey JD, Robbins MB, Moyle RG (2016) A genomic investigation of the putative contact zone between divergent Brown Creeper (Certhia americana) lineages: chromosomal patterns of genetic differentiation. Genome 59:115-125. https://doi.org/10.1139/gen-2015-0093

Mason NA, Taylor SA (2015) Differentially expressed genes match bill morphology and plumage despite largely undifferentiated genomes in a Holarctic songbird. Mol Ecol 24:3009-3025

Mayr E (1942) Systematics and the origin of species. Columbia University Press, New York

McCarthy EM (2006) Handbook of avian hybrids of the world. Oxford University Press, Oxford

McDonald DB, Clay RP, Brumfield RT, Braun MJ (2001) Sexual selection on plumage and behavior in an avian hybrid zone: experimental tests of male-male interactions. Evolution 55:1443-1451

McKay BD, Zink RM (2014) Sisyphean evolution in Darwin's finches. Biol Rev 90:689-698. https://doi.org/10.1111/brv.12127

McLean A, Toon A, Schmidt D, Hughes J, Joseph L (2017a) Phylogeography and geno-phenotypic discordance in a widespread Australian bird, the variegated fairy-wren, Malurus lamberti (Aves: Maluridae). Biol J Linn Soc 121:655-669. https://doi.org/10.1093/biolinnean/blx004

McLean A, Joseph L, Toon A, Schmidt D, Drew A, Mason IJ, Hughes J (2017b) Reassessment of a possible case of intraspecific gene flow across Australia's Great Dividing Range in the variegated fairy-wren, Malurus lamberti (Aves: Maluridae) and its systematic consequences. Biol J Linn Soc 122:210-223. https://doi.org/10.1093/biolinnean/blx054

Mettler RD, Spellman GM (2009) A hybrid zone revisited: molecular and morphological analysis of the maintenance, movement, and evolution of a Great Plains avian (Cardinalidae: Pheucticus) hybrid zone. Mol Ecol 18:3256-3267

Mihailova M, Berg ML, Buchanan KL, Bennett ATD (2014) Odour-based discrimination of subspecies, species and sexes in an avian species complex, the crimson rosella. Anim Behav 95:155-164

Morales HE, Pavlova A, Joseph L, Sunnucks P (2015) Positive and purifying selection in mitochondrial genomes of a bird with mitonuclear discordance. Mol Ecol 24:2820-2837

Morales HE, Sunnucks P, Joseph L, Pavlova A (2017a) Perpendicular axes of differentiation generated by mitochondrial introgression. Mol Ecol 26:3241-3255

Morales HE, Pavlova A, Sunnucks P, Major R, Amos N, Joseph L, Wang B, Lemmon AR, Endler JA Delhey K (2017b) Neutral and selective drivers of colour evolution in a widespread Australian passerine. J Biogeogr 44:522-536

Morales HE, Pavlova A, Amos N, Major R, Bragg J, Kilian A, Greening C, Sunnucks P (2017c) Mitochondrial-nuclear interactions maintain a deep mitochondrial split in the face of nuclear gene flow. bioRxiv preprint first posted online Dec. 20, 2016. https://doi.org/10.1101/095596

Morales-Rozo A, Tenorio EA, Carling MD, Cadena CD (2017) Origin and cross-century dynamics of an avian hybrid zone. BMC Evol Biol 17:257. https://doi.org/10.1186/s12862-017-1096-7

Nater A, Burri R, Kawakami T, Smeds L, Ellegren H (2015) Resolving evolutionary relationships in closely related species with whole-genome sequencing data. Syst Biol 64:1000-1017

Nei M, Roychoudhury AK (1974) Sampling variances of heterozygosity and genetic distance. Genetics 76:379-390

Newton I (2004) Speciation and biogeography of birds. Academic Press, London

Nosil P, Feder JL (2012) Genomic divergence during speciation: causes and consequences. Philos Trans R Soc B Biol Sci 367:332-342

Nosil P, Feder JL, Flaxman SM, Gompert Z (2017) Tipping points in the dynamics of speciation. Nat Ecol Evol 1:1-8. https://doi.org/10.1038/s41559-016-0001

Olsson U, Leader PJ, Carey GJ, Khan AA, Svensson L, Alström P (2013) New insights into the intricate taxonomy and phylogeny of the Sylvia curruca complex. Mol Phylogenet Evol $67: 72-85$ 
Oswald JA, Harvey MG, Remsen RC, Foxworth DU, Cardiff SW et al (2016) Willet be one species or two? A genomic view of the evolutionary history of Tringa semipalmata. Auk 133:593-614

Ottenburghs J, Kraus RHS, van Hooft P, van Wieren SE, Ydenberg RC, Prins HHT (2017) Avian introgression in the genomic era. Avian Res 8:30. https://doi.org/10.1186/s40657-017-0088-z

Ovenden JR, Mackinlay AG, Crozier RH (1987) Systematics and mitochondrial genome evolution of Australian rosellas (Aves, Platycercidae). Mol Biol Evol 4:526-543

Parchman TL, Gompert Z, Braun MJ, Brumfield RT, McDonald DB, Uy JAC, Zhang G, Jarvis ED, Schlinger BA, Buerkle CA (2013) The genomic consequences of adaptive divergence and reproductive isolation between species of manakins. Mol Ecol 22:3304-3317

Parsons TJ, Olson SL, Braun MJ (1993) Unidirectional spread of secondary sexual plumage traits across an avian hybrid zone. Science 260:1643-1646

Pavlova A, Amos JN, Joseph L, Loynes K, Austin JJ, Keogh JS, Stone GN, Nicholls JA, Sunnucks P (2013) Perched at the mito-nuclear crossroads: divergent mitochondrial lineages correlate with environment in the face of ongoing nuclear gene flow in an Australian bird. Evolution 67:3412-3428

Pavlova A, Selwood P, Harrisson KA, Murray N, Quin B, Menkhorst P, Smales I, Sunnucks P (2014) Integrating phylogeography and morphometrics to assess conservation merits and inform conservation strategies for an endangered subspecies of a common bird species. Biol Conserv 174:136-146

Payseur BA, Rieseberg LH (2016) A genomic perspective on hybridization and speciation. Mol Ecol 25:2337-2360

Peñalba JV, Mason IJ, Schodde R, Moritz C, Joseph L (2017) Characterizing divergence through three adjacent Australian avian transition zones. J Biogeogr 44:2247-2258. https://doi.org/10. $1111 /$ jbi. 13048

Peters JL, Zhuravlev Y, Fefelov I, Logie A, Omland KE (2007) Nuclear loci and coalescent method support ancient hybridization as cause of mitochondrial paraphyly between Gadwall and Falcated Duck (Anas spp.). Evolution 61:1992-2006

Peters JL, Winker K, Millam KC, Lavretsky P, Kulikova I, Wilson RE, Zhuravlev YN, McCracken KG (2014) Mito-nuclear discord in six congeneric lineages of Holarctic ducks (genus Anas). Mol Ecol 23:2961-2974

Peterson AT, Anamza T (2017) Reexamining Phylloscopus trochiloides complex as a ring species: a refugial counter-hypothesis. J Avian Biol 48(12):1608-1613. https://doi.org/10.1111/jav. 01167

Poelstra JW, Vijay N, Bossu CM, Lantz H, Ryll B, Müller I, Baglione V, Unneberg P, Wikelski M, Grabherr MG, Wolf JBW (2014) The genomic landscape underlying phenotypic integrity in the face of gene flow in crows. Science 344:1410-1414

Poelstra JW, Vijay N, Hoeppner MP, Wolf JBW (2015) Transcriptomics of colour patterning and coloration shifts in crows. Mol Ecol 24:4617-4628

Price TD (2008) Speciation in birds. Roberts and Company, Greenwood Village

Pryke SR, Griffith SC (2009) Postzygotic genetic incompatibility between sympatric color morphs. Evolution 63:793-798

Qvarnström A, Bailey RI (2009) Speciation through evolution of sex-linked genes. Heredity 102:4-15

Remington CL (1968) Suture-zones of hybrid interaction between recently joined biotas. In: Dobzhansky T, Hecht MK, Steere WC (eds) Evolutionary biology. Springer, New York, pp $321-428$

Rheindt FE, Edwards SV (2011) Genetic introgression: an integral but neglected component of speciation in birds. Auk 128:620-632

Ribas CC, Maldonado-Coelho M, Smith BT, Cabanne GS, d'Horta FM, Naka LN (2012) Towards an integrated historical biogeography of the Neotropical lowland avifauna: combining diversification analysis and landscape evolution. Ornitol Neotrop 23:187-206

Ribeiro AM, Lloyd P, Bowie RCK (2011) A tight balance between natural selection and gene flow in a southern African arid-zone endemic bird. Evolution 65:3499-3514 
Roux C, Fraïsse C, Romiguier J, AnciauxY GN, Bierne N (2016) Shedding light on the grey zone of speciation along a continuum of genomic divergence. PLoS Biol 14:e2000234. https://doi.org/ 10.1371/journal.pbio.2000234

Ruegg K, Anderson EC, Boone J, Pouls J, Smith TB (2014) A role for migration-linked genes and genomic islands in divergence of a songbird. Mol Ecol 23:4757-4769. https://doi.org/10.1111/ mec. 12842

Sæther SA, Sætre G-P, Borge T et al (2007) Sex chromosome-linked species recognition and evolution of reproductive isolation in flycatchers. Science 318:95-97

Sætre G-P, Sæther SA (2010) Ecology and genetics of speciation in Ficedula flycatchers. Mol Ecol 19:1091-1106

Sætre G-P, Cuevas A, Hermansen JS, Elgvin TO, Fernández LP, Sæther SA, Cascio Sætre CL, Eroukhmanoff F (2017) Rapid polygenic response to secondary contact in a hybrid species. Proc R Soc B 284:20170365. https://doi.org/10.1098/rspb.2017.0365

San-Jose LM, Ducrest A-L, Ducret V, Simon C, Richter H, Wakamatsu K, Roulin A (2017) MC1R variants affect the expression of melanocortin and melanogenic genes and the association between melanocortin genes and coloration. Mol Ecol 26:259-276

Schodde R (1997) Psittacidae. In: Houston WMK, Wells A (eds) Zoological catalogue of Australia, vol 37.2. Aves. (Columbidae to Coraciidae). CSIRO Publishing, Melbourne, pp 109-218

Schodde R, Mason IJ (1999) The directory of Australian birds. CSIRO Publishing, Canberra

Scordato ESC, Wilkins MR, Semenov G, Rubtsov AS, Kane NC, Safran RJ (2017) Genomic variation across two barn swallow hybrid zones reveals traits associated with divergence in sympatry and allopatry. Mol Ecol 26(20):5676-5691. https://doi.org/10.1111/mec.14276

Shipham A, Schmidt D, Joseph L, Hughes J (2015) Phylogenetic analysis of the Australian rosella parrots (Platycercus) reveals discordance among molecules and plumage. Mol Phylogenenet Evol 91:150-159. https://doi.org/10.1016/j.ympev.2015.05.012

Shipham A, Joseph L, Schmidt D, Hughes JH (2017) A genomic approach reinforces a hypothesis of mitochondrial capture in eastern Australian rosellas. Auk 134:181-192. https://doi.org/10. 1642/AUK-16-31.1

Short L (1969) Taxonomic aspects of avian hybridization. Auk 86:84-105

Sibley CG (1957) The evolutionary and taxonomic significance of sexual selection and hybridization in birds. Condor 59:166-191

Slender AL, Louter M, Gardner MG, Kleindorfer S (2017) Patterns of morphological and mitochondrial diversity in parapatric subspecies of the Thick-billed Grasswren (Amytornis modestus). Emu - Aust Ornithol 117:264-275. https://doi.org/10.1080/01584197.2017.1313686

Sloan DB, Havird JC, Sharborough J (2017) The on-again, off-again relationship between mitochondrial genomes and species boundaries. Mol Ecol 26:2212-2236

Smadja C, Butlin RK (2011) A framework for comparing processes of speciation in the presence of gene flow. Mol Ecol 20:5123-5140

Smith BT, Harvey MG, Faircloth BC, Glenn TC, Brumfield RT (2014a) Target capture and massively parallel sequencing of ultraconserved elements for comparative studies at shallow evolutionary time scales. Syst Biol 63:83-95

Smith BT, McCormack JE, Cuervo AM, Hickerson MJ et al (2014b) The drivers of tropical speciation. Nature 515:406-409. https://doi.org/10.1038/nature13687

Southcott L, Kronforst MR (2017) A neutral view of the evolving genomic architecture of speciation. Ecol Evol 7:6358-6366. https://doi.org/10.1002/ece3.3190

Sraml M, Christidis L, Easteal S, Horn P, Collet C (1996) Molecular relationships within Australasian waterfowl (Anseriformes). Aust J Zool 44:47-58

Storchová R, Reif J, Nachman MW (2009) Female heterogamety and speciation: reduced introgression of the $\mathrm{Z}$ chromosome between two species of nightingales. Evolution 64:456-471

Sunnucks P, Morales HE, Lamb AM, Pavlova A, Greening C (2017) Integrative approaches for studying mitochondrial and nuclear genome co-evolution in oxidative phosphorylation. Front Genet 8:25. https://doi.org/10.3389/fgene.2017.00025

Swenson NG, Howard DJ (2004) Do suture zones exist? Evolution 58:2391-2397 
Taylor SA, Curry RL, White TA, Ferretti V, Lovette I (2014) Spatiotemporally consistent genomic signatures of reproductive isolation in a moving hybrid zone. Evolution 68:3066-3081

Toews DPL, Irwin DE (2008) Cryptic speciation in a Holarctic passerine revealed by genetic and bioacoustic analyses. Mol Ecol 17:2691-2705

Toews DPL, Campagna L, Taylor SA et al (2016a) Genomic approaches to understanding population divergence and speciation in birds. Auk 133:13-30. https://doi.org/10.1642/AUK-15-51.1

Toews DPL, Taylor SA, Vallender R, Brelsford A, Butcher BG, Messer PW, Lovette IJ (2016b) Plumage genes and little else distinguish the genomes of hybridizing warblers. Curr Biol 26:2313-2318

Toon A, Hughes J, Joseph L (2010) Multilocus analysis of honeyeaters (Aves: Meliphagidae) highlights the spatio-temporal heterogeneity in the influence of biogeographic barriers in the Australian monsoonal zone. Mol Ecol 19:2980-2994. https://doi.org/10.1111/j.1365-294X. 2010.04730.x

Trier CN, Hermansen JS, Sætre G-P, Bailey RI (2014) Evidence for mito-nuclear and sex-linked reproductive barriers between the hybrid Italian Sparrow and its parent species. PLoS Genet 10 (1):e1004075. https://doi.org/10.1371/journal.pgen.1004075

van Doren BM, Campagna L, Helm B, Illera JC, Lovette IJ, Liedvogel M. (2017) Correlated patterns of genetic diversity and differentiation across an avian family. Mol Ecol 26:3982-3997

Voelker G, Outlaw RK, Bowie RCK (2010) Pliocene forest dynamics as a primary driver of African bird speciation. Glob Ecol Biogeogr 19:111-121

Voelker G, Marks BD, Kahindo C et al (2013) River barriers and cryptic biodiversity in an evolutionary museum. Ecol Evol 3:536-545

Winger BM (2017) Consequences of divergence and introgression for speciation in Andean cloud forest birds. Evolution 71:1815-1831

Winger BM, Bates JM (2015) The tempo of trait divergence in geographic isolation: Avian speciation across the Marañon Valley of Peru. Evolution 69:772-787

Yamaguchi R, Iwasa Y (2017) A tipping point in parapatric speciation. J Theor Biol 421:81-92

Younger JL, Clucas GV, Kooyman G, Wienecke B, Rogers AD, Trathan PN, Hart T, Miller KJ (2015) Too much of a good thing: sea ice extent may have forced emperor penguins into refugia during the last glacial maximum. Glob Chang Biol 21:2215-2226. https://doi.org/10.1111/gcb.12882

Open Access This chapter is licensed under the terms of the Creative Commons Attribution 4.0 International License (http://creativecommons.org/licenses/by/4.0/), which permits use, sharing, adaptation, distribution and reproduction in any medium or format, as long as you give appropriate credit to the original author(s) and the source, provide a link to the Creative Commons license and indicate if changes were made.

The images or other third party material in this chapter are included in the chapter's Creative Commons license, unless indicated otherwise in a credit line to the material. If material is not included in the chapter's Creative Commons license and your intended use is not permitted by statutory regulation or exceeds the permitted use, you will need to obtain permission directly from the copyright holder.

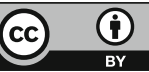

